\section{BA Institute of \\ YK Business Administration \\ 六下 \\ Karachi \\ Leadership and Ideas for Tomorrow}

Business Review

Volume 10 Issue 1 January - June 2015

$1-1-2015$

\title{
Evaluation method, task outcomes and group structure as counteracting strategies of social loafing in manufacturing industries of Pakistan
}

\author{
Khurshid Alam \\ Management Studies University of Malakand, Pakistan \\ Arshad Ali \\ Management Studies University of Malakand, Pakistan \\ Fazli Subhan \\ Management Studies University of Malakand, Pakistan
}

Follow this and additional works at: https://ir.iba.edu.pk/businessreview

Part of the Business Commons, Organization Development Commons, and the Policy Design, Analysis, and Evaluation Commons

\section{(c) (;)}

This work is licensed under a Creative Commons Attribution 4.0 International License.

\section{Recommended Citation}

Alam, K., Ali, A., \& Subhan, F. (2015). Evaluation method, task outcomes and group structure as counteracting strategies of social loafing in manufacturing industries of Pakistan. Business Review, 10(1), 131-146. Retrieved from https://doi.org/10.54784/1990-6587.1319

This article is brought to you by iRepository for open access under the Creative Commons Attribution 4.0 License and is available at https://ir.iba.edu.pk/businessreview/vol10/iss1/11. For more information, please contact irepository@iba.edu.pk. 


\title{
ARTICLE
}

\section{Evaluation Method, Task Outcomes and Group Structure as counteracting strategies of Social Loafing in Manufacturing Industries of Pakistan}

\author{
Khurshid Alam \\ Management Studies University of Malakand, Pakistan \\ Arshad Ali \\ Management Studies University of Malakand, Pakistan \\ Fazli Subhan \\ Management Studies University of Malakand, Pakistan
}

\section{Abstract}

The study examines task evaluation techniques; task outcomes and group structure composition in counteracting social loafing. The approach espoused in this paper is to assess the conventional literature that provides strong support for existence of social loafing phenomenon in groups and to predict counteracting from aforementioned variables.Based on latest literature innovative ways for combating social loafing are discussed. Results provide conclusive support that enhancing evaluation method, task outcomes and group structure were associated with reduced occurrence of social loafing. At group level increased conjunctive task and reward interdependence, heterogeneity and peer evaluation increase social loafing while increase in task meaningfulness, content, intensity, homogeneity, disjunctive and self evaluation reduce social loafing. The paper provides practical implications that enhancing task evaluation techniques, outcomes and group structure reduce social loafing and ultimately increase organizational performance. The study is unique as no one has focused the phenomenon of social loafing in Pakistan, thus it also contribute knowledge to literature.

Keywords: Social Loafing, Evaluation Method, Task Outcome, Group Structure and Manufacturing Industry

\section{Introduction}

Complex and dynamic operations have made organizations and industries unable to carry out their work through individualistic approach and thus create a need for group work. Numerous studies have focused the significance of collective work. Besideshuge benefits it has many shortcomings; as in many cases the sum individual work in group is inferior to the sum of individual work alone which is attributed to individual efforts reduction in collective work. This tendency of individuals refers to social loafing. In social loafing each individual try to get maximum benefits from collective work while exerting little efforts. Consequently most of individuals consider collective work as unsatisfactory experience and have less motivation towards collective goals of the organization. Hoon and Tan (2008) argue that for understanding collective work; studying social loafing, its roots and corollaries are indispensable. 
In nineteenth century 1913 Max Ringelmann observed decreased individual performance in thegroup experiment of "Rope Pulling" and "Swimming in Conveys". According to Kravitz and Martin (1986), Ringelmann always found less magnitude of group performance than individual performance for the same number of individuals. Soon after this reduced performance phenomenon was confirmed in experiments of "Clapping and Shouting" (Latane, Williams, \& Harkins, 1979). This phenomenon was named social loafing (Liden, Wayne, Jaworski, \& Bennett, 2004). Chidambaram and Tung (2005) argue that social loafing decrease actual performance of individuals and organizations and is treacherous phenomenon for organizations and should be properly researched. It has received massive concentration from social scientists in last many years (Bastiaans \& Nauta, 2003).

Different authors haveemphasized significant causes of social loafing at work places, these include incompetency of group members (Latane et al., 1979), poor social coordination (Steiner, 2007), communalappraisal(Karau \& Williams, 1993), collective incentives (Jackson \& Harkins, 1985) andtrust on appraiser(Latane et al., 1979). Other drivers include group performance techniques (Kidwell \& Bennett, 1993) effort results(Harkins \& Jackson, 1985) and group structure(Hardy \& Crace, 1991).To the best of our knowledge these methods (evaluation method, task outcomes and group structure) have never been addressed in Pakistani context, this study is therefore of unique nature. To fill this void and to increase human efficiency this study is designed to explore certain aspects of increasing individual and group performance. The central objective of the study is to examine the relationship of evaluation methods, task outcomes and group structure with social loafing, because all rewards depend upon task outcomes and evaluation techniques while group structure determine individual contribution towards collective goals. It may add different strategies for reduction of loafing and consequently it may contribute to individual life standards, national and international economy due to enhanced individual and group productivity, efficiency and effectiveness.

\section{Literature Review}

\section{Social Loafing}

The tendency of exerting less effort in collective work as compared to individual work refers to social loafing (Latane et al., 1979). It is also called Free Rider Effect, because in social loafing the loafer reap collective benefits and don't contribute fair share in inputs (Aggarwal \& O'Brien, 2008). Davies (2009) argue that social loafing direct individual towards free riding and thus individuals don't exert full efforts in collective work.

\section{Evaluation Method}

Evaluation is the organized analysis of expected and actual results and it looks for expected and actual objectives and its way of accomplishment (Russ-Eft, 2009). It is a logical, precise and thorough application of scientific methods to evaluate objectives designing, its execution and enhancement in outcomes. It require appraisalproficiency, effort, time and substantial budget(Lipsey, Freeman, \& Rossi, 2004).

Szymanski and Harkins (1987) argue that social loafing is caused by lack of justified evaluation and weak internal and external assessment potential. According to Thompson (2004) loafing can be reduced by providing performance feedback to individuals on their individual outcomes by apparent performance standards. Individuals are less motivated when they perceive that their rewards are not justified with their inputs (Kidwell \& Bennett, 1993) whileBrewer (1995) argue that an individual concern on evaluation of performance affect the overall performance. Worchel, Rothgerber, Day, Hart, and Butemeyer (1998) argue high 
productivity of group members while working for group based rewards than for an individual incentive in social situation. This assumption support social identity that an individual who consider group efforts more important will work for achieving collective outcomes. Worchel et al. (1998) further argue increased productivity in group setting than alone in an experiment when evaluator group was physically presentand less productivity than individual productivity when evaluator group was not present for evaluation. Williams, Nida, Baca, and Latané (1989) also argue significant positive relationship among swimmers in relays under high efforts identifiability than low identifiability. Worchel et al. (1998) concluded that highest productivity is associated with greater tendency of categorizing individuals as a group, evaluative group, identifiability in a group, impact of group behavior on individual, interest of group part and thinking about group.

Comer (1995) found that individual supremacy to co-worker on conjunctive task or inferiority on disjunctive task increase loafing by amplifying the perception of being one superfluous to do the work of group because individuals compare their abilities and performance with group members (Goethals \& Darley, 1987). Worchel et al. (1998) argue that conjunctive and disjunctive rewards should create less loafing than additive condition because conjunctive and disjunctive rewards have strong link between individual performance and group performance. That is if an individual work hard in disjunctive task, the probability ofgroup performance will increase and vice versa. Veigal (1991) describe another aspect that the perception of coworker about highly qualified colleagueand better performance curb individuals efforts, ability and perception of own competency and productivity than others in a group. It will enhance his/her proclivity to loafing due to lack of influence over task outcomes (Comer, 1995). Szymanski and Harkins (1987) argues that social loafing was eliminated when individual performance was evaluated rather than collective evaluation. According to Gerhart and Rynes (2003) individuals can be motivated by aligning individual goals with group and organizational goals; and with individual rewards. Based on the above literature review, authors hypothesize that:

H1: Social loafing will be high if there are conjunctive task and rewards.

$\mathrm{H} 2$ : Social loafing will be low if there are disjunctive task and rewards.

Social loafing may be reduced through self and peer evaluation systems. Suleiman and Watson (2008)argue reducedsocial loafing in self feedback system. Individuals who engage in self enhancing loafing give the impression to group members that they are just lazy rather than incompetent (Comer, 1995). While some authors argue peer evaluation as a best tool for individual accountability and efficiency(Brooks \& Ammons, 2003). But its use may encourage and create undesirable situation in organizations. Strong and Anderson (1990)argue that peer evaluations are the least effective tools for group performance improvement. This perception have made the use of peer evaluation very rare (Falchikov \& Goldfinch, 2000). Peer rating can change group cohesiveness, group harmony and group performance (DeNisi, Randolph, \& Blencoe, 1983). Price (1987) conducted an experiment in which one group was supposed to give opinion about the business and other is supposed to make a decision. In decision making there was no evaluation potential so group members loafed greater than another group who are supposed to give an opinion about business, because the output of opinion makers was to be evaluated. On the other side Griffith, Fichman, and Moreland (1989) found that evaluation showed no effect on task performance in more complicated tasks like solving maze problems. Harkins and Szymanski (1989) argues that social loafing can be reduced by implementing individual and group evaluation system. Social loafing is more likely to occur when no standards exists for individual evaluation with 
group evaluation (Comer, 1995). Based on above literature authors conclude following hypothesis:

H3: Social loafing can be reduced through self feedback mechanism than peer evaluation.

\section{Task Outcomes}

Task outcomes are the products and services that an individual produce at work place. Group members can be motivated enoughif their outcomes are evaluated individuallyinstead of collective outcome (Harkins \& Jackson, 1985). Individuals can be motivated either by significanceand uniqueness of task outcome for organization and individuals, this refers to task meaningfulness or by prettytangible and intangible rewards of a certain task(George, 1992).Locke, Cartledge, and Koeppel (1968)argue that goals are immediate regulators of human behavior and action. According to Gerhart and Rynes (2003) individuals can be motivated by aligning individual goals with group and organizational goals; and with individual rewards.Rand (1990) found that content and intensity are the two major attributes of individual effort. Content refers to what is expected from an individual, these are clarity, precision and difficulty (Locke, Shaw, Saari, \& Latham, 1981)while intensity refers to the process of goal setting, it include degree of effort, scope of task and importance of goal (Locke et al., 1981). Karau and Williams (1993) concluded that social loafing occur because of the perception of intense individual effort and dividing valued outcome among group members.

Locke et al. (1981)argue that specific, clear and challenging goals lead to higher performance than easy goals and directing concentration, increasing persistence, mobilizing efforts and motivating strategy development affect an individual goals and performance. Locke et al. (1981) further describe that assigned goals, feedback on performance, financial rewards and supportive management increase performance and providing feedback on the evaluation of individual performance lead to higher performance. Incentive in the form of money is a powerful motivator of performance (Locke, Feren, McCaleb, Shaw, \& Denny, 1980). Locke et al. (1981) argue that the degree of commitment depends upon the financial incentive offered while goal setting theory argues that goal commitment influence performance (Locke \& Latham, 1990). Klehe and Anderson (2007) argue that loafing may be reduced when an individual is given high valence task (high task meaningfulness) and more personal involvement. Discussing above literature authors arrives at hypothesizing that:

H4: Social loafing will be low if task meaningfulness is high.

H5: Social loafing will be low if content and intensity are high.

\section{Group Structure}

According to Payne and Pugh (1976)group structure is viewed as stable arrangement of people, having division of labor and job specialization, control and coordination. Working in collective structure, utilizing individual efforts and dividing rewards equally among group member create social dilemma (Glance \& Huberman, 1994).Pfeffer (1995) argues that collective norms, shared values and colleague pressure can overcome this social dilemma. Becker and Baloff (1969) argue that group structure influence group effectiveness. While Hardy and Crace (1991) found that group structure has minimal effect on social loafing. Group effectiveness can be achieved indirectly through group process by grouping and arranging group structures and groups having clear goal communicated openly (Kiesler, 1978). Individuals belonging to different group structure will behave in different ways.Researchers Pugh, Hickson, Hinings, and Turner (1968)argue different constructs of 
group structure like group size, group goals clarity, group roles clarity, group norms, controlling task and group leadership. So goal, role and norm structure different activities.

Kiesler (1978)argue that group having clear vision and clear goals communicate openly than groups having unclear vision and goals. Gladstein (1984) found that open communications, supportiveness, training, active leadership and practical experience in organizations has positive impact on employee's satisfaction and organizational performance. Loch, Huberman, and Stout (2000) argue that status competition can drive team members to use maximum efforts. But if this status can be achieved through political manipulation then it leads to decrease overall performance. Loch et al. (2000)arguesthat group performance will be stable if shared ranks are allowed in the group. The performance of heterogeneous groups is less effective than homogenous groups during early establishment of group (Watson, Kumar, \& Michaelsen, 1993).Shea and Guzzo (1987)argue task outcome and task interdependence as keys to group effectiveness.Outcome interdependence is the degree in which an individual receive his/her rewards depend upon the performance of others while in non interdependence an individual receive rewards only for his/her own performance (Wageman, 1995). High interdependent teams utilize collective knowledge and skills of their own group members. They demonstrate extensive shared learning, high class social processes and wisdom of collective responsibility for collective performance (Wageman, 1995). Wageman and Baker (1997) define task interdependence as the degree to which the task performance of one individual depend upon the efforts and skills of other individual while reward interdependence is the degree to which the reward of an individual depend upon the efforts of others. Rees, Zax, and Herries (2003) argue that significant interdependencies exist that could arise from group based compensation, peer pressure, common supervisor or exchanging information. Wageman and Baker (1997) argue that the failure in adequately designing group task and group rewards create much confusions. The confusion may arise how to divide work among group members and how the rewards should be given on individual performance or group performance or combination of both. Wageman and Baker (1997) found no significant difference in performance between highly interdependent and less interdependent tasks designs.

Trust (Edmondson, 1999), pay structure (Lawler, 2000), training and coordination (Marks, Sabella, Burke, \& Zaccaro, 2002), group member composition (Barrick, Stewart, Neubert, \& Mount, 1998) differentiate effective groups from non effective groups. Comer (1995) suggested that the group structure should be built in such a method to bring unique set of skills, having comparable levels at their respective areas of expertise. This will increase each member perceived indispensability and perceived influence over task outcomes. Worchel et al. (1998)argue thatunfamiliar colleagues reduce their productivity in collective work and Individuals don't increase efforts in social setting when group works for collective rewards. Profit sharing is an important determinant of success in group work (Belman, Drago, \& Wooden, 1992). Based on above literature authors hypothesize that:

H7: Social loafing will be high if there is high task interdependence and reward interdependence.

H8: Social loafing in homogenous group structure is low than heterogeneous group structure. 


\section{Research Model}

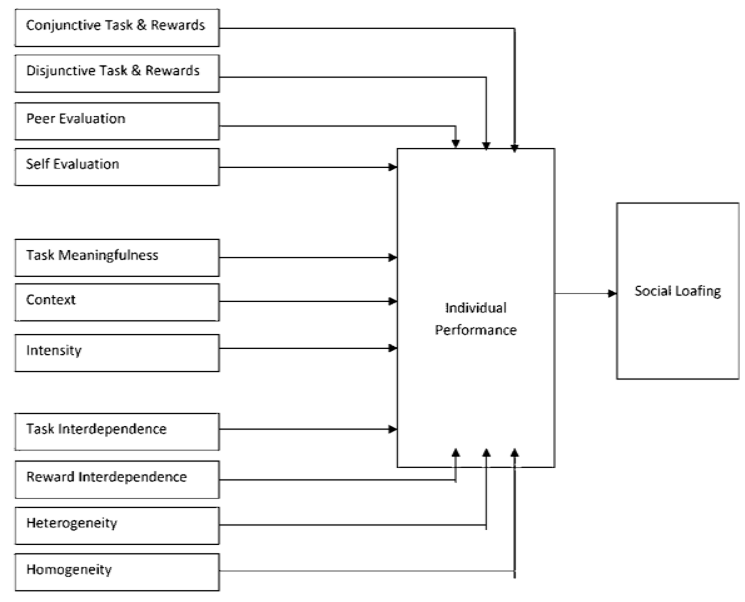

\section{Methodology}

This portion of the paper examines different statistical tools used for data analysis.

\section{Designing of Questionnaire}

Survey questionnaire was developed with study of previous literature and with due conference of senior research associates. It was pre-tested on a cluster of senior professional experts in the field for enhancing the understandability and comprehension of the instrument prepared.

Survey questionnaires are considered the best data collection tool due to the reason of enhanced external validity. In survey questionnaire data is collected form specific and identified group of people about their ideas, information and behavioral observations regarding some phenomenon, thiscreate greater generalizability of the study (Brownell, 1995). Other reasons for selection of survey questionnaire are simple, economical and rapid data collection. It is more consistent and objective for collecting and analysis of large amount of information in less time (Bachmann, Elfrink, \& Vazzana, 1996; Wright, 2005). Besides advantages it has demerits as well,

for example difficult to understand, tick box policy and untrustworthy answers(Goodman, 1997). For eliminating any complication and distortion semi structured interviews were conducted (Pallant, 2010). This further enhanced generalizability of the study.

\section{Pilot Survey}

Pilot study and test retest upon 27 respondents were conducted to enhance the external validity and reliability of the instrument prepared. Pilot study is most significant phase of survey development(Rubin \& Babbie, 2013). Various explanations, recommendations and suggestions of these respondents were included in the next version of the survey. This increased the generalizability of the instrument(Brownell, 1995). Coefficients of internal consistency for all variables show a good measure of alpha. 


\section{Data Collection}

Survey questionnaires with reference consultation and face to face semi structured interviews were used for data collection. Total 300 questionnaires were administered and 181 responses were received, this shows $60 \%$ return rate. 55 questionnaires were disposed off due to incomplete information.

\section{Sample Selection}

Respondents from departments of production, sales and marketing of manufacturing industries in Pakistan were selected through stratified random sampling. This technique has advantages of statistical efficiency, accurate representation and enough data collection (Cooper \& Schindler, 2003).

\section{Univariate Analysis}

Analysis of Variance (ANOVA) was performed for comparison of mean score of different sectors and insignificant results were found except content and intensity, i.e. task outcomes. Marketing and sales departments differ from manufacturing department in task outcomes, Table No 2. The respondents were from three sectors, including sales $(\mathrm{n}=56)$, marketing $(n=20)$ and manufacturing $(n=50)$. It is concluded that there is no difference among different sectors and results of the study can be generalized to all sectors.Levene test and Kolmogorov tests were performed to check homoskedasticity and normality of data and insignificant results were found showinghomoskedasticity and normality of the data. The analysis of White test statistic also shows insignificant result which indicates the presence of homoskedasticity in data.

\section{Multicollinearity}

Multicollinearity shows relationship among different independent variables. Multicollinearity was calculated through variance inflation factors (VIF) and tolerance statistics. Tolerance statistic shows variability that is not explained by other independent variables. The result of variance inflation factors and tolerance statistics Table No 3 shows the absence of Multicollinearity in the data; this was also supported by tolerance values.

\section{Standard Multiple Regressions}

Standard multiple regression allows the forecast of one dependent variable from many independent variables. It also describes projecting power of each individual variable in the prediction of dependent variable. It is more sophisticated investigation of interrelationship among a set of independent and dependent variables. It also helps in investigation of more complicated association. In this study we included all constructs of independent variables including task meaningfulness, conjunctive evaluation, disjunctive evaluation, Content, reward interdependency, peer evaluation, homogeneity and heterogeneity.

Data fulfill all assumptions of multiple regressions including sample size and no outliers were found as defined by (Tabachnick \& Fidell, 2001) with residual values greater than 3.3 or less than -3.3. A significant regression value of 28.5 was found and it is concluded that above mentioned variables are accounted for $28.5 \%$ (Table No 4 ) of reduction of social loafing. Hence it is argued that there are some other factors as well in reduction of social loafing phenomenon. Values of beta (Table No 3) show the individual prediction of each variable in collective prediction. In independent variables task evaluation method account much more for social loafing. Thus it can be interpreted that organizations may reduce social loafing by enhancing task evaluation methods. Authors studied task evaluation methods from two angles and it was found that conjunctive task evaluation method create more loafing with 
increase of this type evaluation while disjunctive task and reward has negative relationship with social loafing. It was also identified in interviews that individuals can be motivated and their performance can be increased enough through disjunctive tasks and rewards and they prefer individual task and rewards.

Table No 4: Standard Multiple Regression Model Summary

\begin{tabular}{lrrrr}
\hline \hline Model & R & R Square & \multicolumn{1}{c}{$\begin{array}{c}\text { Adjusted R } \\
\text { Square }\end{array}$} & $\begin{array}{c}\text { Std. Error of the } \\
\text { Estimate }\end{array}$ \\
\hline 1 & $.534^{\mathrm{a}}$ & .285 & .216 & .44607 \\
\hline \hline
\end{tabular}

\begin{tabular}{llrrrrr}
\hline \hline \multicolumn{7}{c}{ ANOVA $^{\mathbf{b}}$} \\
\hline Model & Sum of Squares & Df & Mean Square & F & Sig. \\
1 & Regression & 9.058 & 11 & .823 & 4.138 & $.000^{\mathrm{a}}$ \\
& Residual & 22.683 & 114 & .199 & & \\
& Total & 31.741 & 125 & & &
\end{tabular}

a. Predictors: (Constant), Hmgnty, Rwrd_intrdpnd, Peer_Evlutn, Cntnt, Evl_Conjnctve, Evl_Disjnctve, Intnsty, Tsk_Mngflns, Hetrgnty, Self_Evlutn, Tsk_intrdp

b. Dependent Variable: SL

\section{Interpretation and Discussion}

The central theme of the study is to determine the relationship and prediction of social loafing elimination from evaluation methods including conjunctive and disjunctive task and rewards, self and peer evaluation systems, task outcomes including task meaningfulness, content, intensity, task and rewards interdependence, heterogeneity and homogeneity of group structure.

Data fulfill all assumptions of linear correlation and standard multiple regression and support all null hypotheses under consideration and it is concluded that social loafing is observed more in conjunctive task and rewards allocation mechanism as compared to disjunctive task and rewards. Conjunctive task and rewards have significant direct relationship while disjunctive task and rewards have significant inverse relationship with social loafing. It can be interpreted that a task having high interdependence upon group members face huge dilemmas of social loafing as compared to task having low dependence upon group members. It may be argued that in conjunctive task and rewards there is reduction in group process efficiency and effectiveness. This inclination towards loafing may be due to variety of huge interpersonal processes and either motivation or coordination losses. On the other side disjunctive task and rewards reduce loafing and people are more committed towards individual performance and organizational goals, because Thompson (2004) argue that individuals like individual feedback on individual performance than collective feedback on collective performance and any concern on evaluation affects overall performance. Comer (1995)describe the reason behind loafing is individual supremacy on conjunctive task or inferiority on disjunctive task and because individuals compare their abilities and efforts with others. The findings of these hypotheses are consistent with Szymanski and Harkins (1987), while inconsistent with Worchel et al. (1998), they were of opinion that incompetent 
individual exert more efforts in proficient group and this phenomenon refers to Kohler effect. Further peer evaluation has direct while self evaluation has inverse relationship with social loafing showing consistency withSuleiman and Watson (2008).

A significant inverse relationship was found between task meaningfulness and social loafing. Thus it is concluded that if task is of high value, unique and significant then there will be low tendency towards loafing and corroborating(George, 1992). Content and intensity both have significant inverse relationship with social loafing. Content refers to clarity, efficiency, and precision expected from individuals while intensity refers to process of objectives and goal setting. The study shows inverse relationship indicating that increase in goals clarity; efficiency, effectiveness and enhancement of goal setting process will decrease social loafing showing consistency with (Kremer \& McGuinness, 1998; Ness \& Patton, 1979).

Further it was found that both task and rewards interdependence lead towards social loafing. However task interdependence has significant direct relationship with social loafing and is responsible for creation of more loafing than reward interdependence showing consistency with (Wageman, 1995).

It was found that group heterogeneity has direct relationship while group homogeneity has inverse relationship with social loafing. heterogenic group structure face more challenges and dilemmas due to diverse mix of people while homogeneous group structure face lesschallenges due to homogeneous group of people. Homogenous people feel easy to work with known colleague while in heterogeneous group each member is reluctant to use efforts showing inconsistency with (Worchel et al., 1998) while consistency with (Watson et al., 1993).

\begin{tabular}{|c|c|c|c|c|c|c|c|c|c|c|c|c|c|c|}
\hline & & & Evl_Conjn & Evl_Disjn & c Peer_E & Self_Evlu & Tsk_Mng & & & & & Rwrd_i & & \\
\hline & & SL & ctve & tve & tn & tn & flns & Rwds & Cntnt & Intnsty & Tsk_intrdp & pnd & Hetrgnty & Hmgnty \\
\hline \multirow[t]{2}{*}{ SL } & Pearson Correlation & 1 & & & & & & & & & & & & \\
\hline & Sig. (2-tailed) & & & & & & & & & & & & & \\
\hline \multirow[t]{2}{*}{ Evl_Conjnctve } & Pearson Correlation & $.228^{\circ}$ & 1 & & & & & & & & & & & \\
\hline & Sig. (2-tailed) & .010 & & & & & & & & & & & & \\
\hline \multirow[t]{2}{*}{ Evl_Disjnctve } & Pearson Correlation & $-384^{* \prime}$ & -.058 & 1 & & & & & & & & & & \\
\hline & Sig. (2-tailed) & .000 & .521 & & & & & & & & & & & \\
\hline \multirow[t]{2}{*}{ Peer_Evlutn } & Pearson Correlation & $.180^{\circ}$ & -.013 & -.101 & 1 & & & & & & & & & \\
\hline & Sig. (2-tailed) & .043 & .884 & .261 & & & & & & & & & & \\
\hline \multirow[t]{2}{*}{ Self_Evlutn } & Pearson Correlation & $-311^{*}$ & .162 & $.516^{\circ}$ & -.069 & 1 & & & & & & & & \\
\hline & Sig. (2-tailed) & .000 & .070 & .000 & .440 & & & & & & & & & \\
\hline \multirow[t]{2}{*}{ I'sk_Mngflns } & Pearson Correlation & $-296 "$ & .102 & $.628^{* \prime}$ & - & $.166^{* *}$ & 1 & & & & & & & \\
\hline & Sig. (2-tailed) & .001 & .254 & .000 & .869 & .000 & & & & & & & & \\
\hline \multirow[t]{2}{*}{ Cntnt } & Pearson Correlation & $-210^{\circ}$ & -.001 & -.054 & $-.244^{*}$ & .132 & .005 & $.927^{* *}$ & 1 & & & & & \\
\hline & Sig. (2-tailed) & .018 & .987 & .547 & .006 & .141 & .960 & .000 & & & & & & \\
\hline \multirow[t]{2}{*}{ Intnsty } & Pearson Correlation & $-.215^{\circ}$ & -.006 & .085 & $-.275^{*}$ & $.220^{*}$ & .149 & $.850^{* *}$ & $.766^{*}$ & 1 & & & & \\
\hline & Sig. (2-tailed) & .016 & .944 & .346 & .002 & .013 & .097 & .000 & .000 & & & & & \\
\hline \multirow[t]{2}{*}{ Tsk_intrdp } & Pearson Correlation & $.252^{\prime \prime}$ & $.934^{* *}$ & -.118 & .063 & .155 & .100 & -.029 & -.007 & -.029 & 1 & & & \\
\hline & Sig. (2-tailed) & .004 & .000 & .187 & .487 & .083 & .264 & .744 & .938 & .749 & & & & \\
\hline \multirow[t]{2}{*}{ Rwrd_intrdpnd } & Pearson Correlation & .174 & $.216^{*}$ & -.105 & .003 & .059 & .049 & -.021 & .007 & -.035 & $.400^{* *}$ & 1 & & \\
\hline & Sig. (2-tailed) & .052 & .015 & .240 & .970 & .510 & .589 & .818 & 940 & .694 & .000 & & & \\
\hline \multirow[t]{2}{*}{ Hetrgnty } & Pearson Correlation & .154 & $.354^{*}$ & .022 & -.002 & .089 & .149 & -.064 & -.060 & -.048 & $.546^{*}$ & $.859^{* *}$ & 1 & \\
\hline & Sig. (2-tailed) & .085 & .000 & .811 & .986 & .320 & .095 & .477 & .502 & .595 & .000 & .000 & & \\
\hline \multirow[t]{2}{*}{ Nty } & Pearson Correlation & $-302^{* *}$ & .164 & $.543^{*}$ & -.083 & $.965^{*}$ & $.763^{*}$ & $.176^{\circ}$ & .101 & $.191^{\circ}$ & .140 & .058 & .080 & 1 \\
\hline & Sig. (2-tailed) & .001 & .066 & .000 & .357 & .000 & .000 & .048 & .261 & .032 & .117 & .520 & .371 & \\
\hline
\end{tabular}




\section{Conclusion}

In conjunctive task and rewards the performance and rewards of each individual depend upon others and whole group contribute to the end product. Thus it may be argued that group performance is the consequence and sum of individual tasks and efforts. A conjunctive task can't be completed until each individual complete his/her own fair share and its efficiency and effectiveness depends upon each individual performance, velocity and quality. Conversely if any one of group members doesn't utilize full efforts then group will suffer from losses.

Based on above discussion and conclusion it is suggested that organizations may avoid social loafing by assigning tasks in disjunction approach rather in conjunction, because in conjunctive task and rewards each individual will be tied with others. Thus overall performance may be affected while in disjunctive task and rewards each individual is responsible for own task and rewards and there is no dependency on collective work. Thus there is low inclination towards social loafing in disjunctive task and rewards. Further it was identified in interviews of senior professionals in Pharma industries that conjunctive or disjunctive task allocation is not a concern but rewards needs to be disjunctive always, each individual like collective work but prefer individual rewards for own contributions.

From the results of the study it was also found that peer evaluation face more loafing than self evaluation. It was identified in interviews that at work place politics and conflicts peers evaluation lead to biased ratings. So peer evaluation may be avoided for reduction of future problems and 360 degree feedback mechanism ${ }^{1}$ was suggested.

Task significance and uniqueness attracts individuals to work hard and they feel inner satisfaction and stimulus for being producing unique goods and service. It was also identified in interviews that individuals try to create name and fame through creation of unique and distinctive goods and services; they are more willing to serve organizations which have no alternate person for a specific task. So organizations may make each task more attractive and unique so that people become attracted towards it and thus social loafing can be minimized. Other strategies for reduction of social loafing are: organizations may focus on goal setting process, goal clarity and efficiency and precision for reducing social loafing. If goals are clear and distinctive in nature then individuals are more motivated towards achievement of goals efficiently and effectively.

Increasing task and rewards interdependence increase loafing tendency among individuals. It is due to the fact that individuals in task interdependency individual's performance depends upon others performance and due to loafing of one individual all group member's performance is affected. As has been discussed earlier, individuals like to receive rewards for own performance and prefer disjunctive task and rewards.

Homogeneous group provide more conducive environment for performance and people feel more satisfied. Authors are talking in the context of Pakistan, people want to work in homogeneous group having huge interaction and relationship among each other's and don't

${ }^{1}$ 360-degree feedback include direct feedback from subordinates, peers, supervisors as well as self evaluation 
like to exert full efforts in group having unknown group members. In Pakistani culture people feel more satisfied if they work and perform with friends and relatives.

\section{Suggestions}

In the light of above for and against arguments it is concluded that organizations may practice disjunctive task and rewards system because individual like separate goals and rewards and thus overall performance may not be affected by individual tasks because of untied distribution of tasks and rewards. Further it is argued that if an organization can't distribute tasks then at least organization may manage individual rewards distribution, because each individual prefer individual rewards. Social loafing may be reduced by the establishmentof self evaluation system rather than other systems, because it is most suitable method for reduction of social loafing.

Each task might be made unique, distinctive and attractive, it has many benefits while its dark side was also identified in interviews that if an individual produce goods and services of unique nature then they demand distinctive perks and privileges from organizations and if organization don't provide those rewards then their motivation becomes low and they exert less effort, thus social loafing dilemma is produced, so organization may focus on creating task uniqueness and keep individuals motivated and satisfied enough through attractive rewards and returns.

It is suggested that organization may practice homogeneous group composition rather than heterogeneous because in Pakistani culture people like to work with known colleague and thus their performance can be increased and social loafing can be reduced.

\section{Implications:}

Current study explored diverse aspects for reduction of social loafing from organizations. These are group evaluation techniques, task outcome evaluation and group structure composition. The study will add literature for academic researchers for further exploration and will enhance understanding of social loafing dilemma in the context of Pakistan. The beneficiaries of the study are different stakeholders of local and global economy including manufacturing industries, student groups, advertisement and marketing teams, military conveys and all service sector organizations. Implyingthese strategies will counteract social loafing and willincrease individual performance, group performance and ultimately organizational performance. Consequently it will contribute to individual life standards, local economy and global economy in the form of enhanced productivity, efficiency and effectiveness and will built capability of managers to cope up with loafing in $21^{\text {st }}$ century.

\section{Future Research Directions}

Future researchers are directed to investigate a more comprehensive study of other constructs of evaluation method, group structure and task outcomes. Other dimensions of evaluation method are qualitative and quantitative evaluation andgroup structure hierarchy includes functional specialization, relationship, while task outcome constructs include task complexity, process and uniqueness.It is also suggested that its impact should be determined moderatingby gender that is there any difference among males and females perceptions and some other industries and organizations of Pakistan. 
https://ir.iba.edu.pk/businessreview/vol10/iss1/11

DOI: https://doi.org/10.54784/1990-6587.1319

Business Review - Volume 10 Number 1

January - June 2015

Appendices - Table No 2: ANOVA

\begin{tabular}{|c|c|c|c|c|c|c|}
\hline \multicolumn{7}{|c|}{ ANOVA } \\
\hline & & Sum of Squares & $\mathrm{df}$ & Mean Square & $\mathrm{F}$ & Sig. \\
\hline \multirow[t]{3}{*}{ SL } & Between Groups & .547 & 2 & .273 & 1.078 & .343 \\
\hline & Within Groups & 31.194 & 123 & .254 & & \\
\hline & Total & 31.741 & 125 & & & \\
\hline \multirow[t]{3}{*}{ Evl_Conjnctve } & Between Groups & 1.555 & 2 & .777 & 2.172 & .118 \\
\hline & Within Groups & 44.025 & 123 & .358 & & \\
\hline & Total & 45.580 & 125 & & & \\
\hline \multirow[t]{3}{*}{ Evl_Disjnctve } & Between Groups & .171 & 2 & .086 & .234 & .792 \\
\hline & Within Groups & 45.088 & 123 & .367 & & \\
\hline & Total & 45.260 & 125 & & & \\
\hline \multirow[t]{3}{*}{ Peer_Evlutn } & Between Groups & 4.355 & 2 & 2.177 & .690 & .504 \\
\hline & Within Groups & 388.280 & 123 & 3.157 & & \\
\hline & Total & 392.635 & 125 & & & \\
\hline \multirow[t]{3}{*}{ Self_Evlutn } & Between Groups & 1.001 & 2 & .500 & 2.227 & .112 \\
\hline & Within Groups & 27.634 & 123 & .225 & & \\
\hline & Total & 28.635 & 125 & & & \\
\hline \multirow[t]{3}{*}{ Tsk_Mngflns } & Between Groups & .091 & 2 & .046 & .178 & .837 \\
\hline & Within Groups & 31.401 & 123 & .255 & & \\
\hline & Total & 31.492 & 125 & & & \\
\hline \multirow[t]{3}{*}{ Cntnt } & Between Groups & 22.152 & 2 & 11.076 & 6.726 & .002 \\
\hline & Within Groups & 202.562 & 123 & 1.647 & & \\
\hline & Total & 224.714 & 125 & & & \\
\hline \multirow[t]{3}{*}{ Intnsty } & Between Groups & 6.168 & 2 & 3.084 & 5.951 & .003 \\
\hline & Within Groups & 63.744 & 123 & .518 & & \\
\hline & Total & 69.912 & 125 & & & \\
\hline \multirow[t]{3}{*}{ Tsk_intrdp } & Between Groups & .845 & 2 & .422 & 1.137 & .324 \\
\hline & Within Groups & 45.687 & 123 & .371 & & \\
\hline & Total & 46.532 & 125 & & & \\
\hline \multirow[t]{3}{*}{ Rwrd_intrdpnd } & Between Groups & 1.068 & 2 & .534 & .461 & .631 \\
\hline & Within Groups & 142.424 & 123 & 1.158 & & \\
\hline & Total & 143.492 & 125 & & & \\
\hline \multirow[t]{3}{*}{ Hetrgnty } & Between Groups & 1.764 & 2 & .882 & .794 & .454 \\
\hline & Within Groups & 136.664 & 123 & 1.111 & & \\
\hline & Total & 138.429 & 125 & & & \\
\hline \multirow[t]{3}{*}{ Hmgnty } & Between Groups & .966 & 2 & .483 & 2.197 & .115 \\
\hline & Within Groups & 27.034 & 123 & .220 & & \\
\hline & Total & 28.000 & 125 & & & \\
\hline
\end{tabular}


Table No 3: Multicollinearity Statistics

\begin{tabular}{|c|c|c|c|c|c|c|c|c|}
\hline \multicolumn{9}{|c|}{ Coefficients $^{\mathrm{a}}$} \\
\hline \multirow{12}{*}{1} & & $\begin{array}{l}\text { Unsta } \\
\text { Coeffi }\end{array}$ & dized & $\begin{array}{l}\text { Standardized } \\
\text { Coefficients }\end{array}$ & & & Collinearit & Statistics \\
\hline & $\begin{array}{l}\text { Model } \\
\text { (Constant) }\end{array}$ & $\begin{array}{l}\text { B } \\
2.568\end{array}$ & $\begin{array}{l}\text { Std. Error } \\
.444\end{array}$ & Beta & $\begin{array}{l}\mathrm{t} \\
5.779\end{array}$ & $\begin{array}{l}\text { Sig. } \\
.000\end{array}$ & Tolerance & VIF \\
\hline & Evl_Disjnctve & -.178 & .092 & -.213 & -1.945 & .054 & .515 & 1.941 \\
\hline & Evl_Conjnctve & .158 & .077 & .190 & 2.045 & .043 & .719 & 1.390 \\
\hline & Peer_Evlutn & .035 & .024 & .123 & 1.466 & .145 & .876 & 1.141 \\
\hline & Tsk_Mngflns & -.080 & .140 & -.079 & -.569 & .571 & .318 & 3.149 \\
\hline & Cntnt & -.046 & .053 & -.122 & -.873 & .384 & .315 & 3.176 \\
\hline & Intnsty & .005 & .088 & .007 & .052 & .959 & .358 & 2.792 \\
\hline & Grp_strctr & .091 & .104 & .080 & .869 & .387 & .724 & 1.381 \\
\hline & Rwrd_intrdpnd & .062 & .082 & .132 & .759 & .449 & .205 & 4.872 \\
\hline & Hetrgnty & .002 & .085 & .004 & .021 & .983 & .195 & 5.126 \\
\hline & Hmgnty & -.183 & .142 & -.172 & -1.285 & .201 & .346 & 2.891 \\
\hline
\end{tabular}

\section{References}

Aggarwal, P., \& O'Brien, C. L. (2008). Social loafing on group projects structural antecedents and effect on student satisfaction. Journal of Marketing Education, 30(3), 255-264.

Bachmann, D., Elfrink, J., \& Vazzana, G. (1996). Tracking the progress of e-mail vs. snailmail. Marketing Research, 8, 31-35.

Barrick, M. R., Stewart, G. L., Neubert, M. J., \& Mount, M. K. (1998). Relating member ability and personality to work-team processes and team effectiveness. Journal of Applied Psychology, 83(3), 377.

Bastiaans, N., \& Nauta, A. (2003). Free-riding and team performance in project education: University of Groningen, Research Institute SOM (Systems, Organisations and Management).

Becker, S. W., \& Baloff, N. (1969). Organization structure and complex problem solving. Administrative Science Quarterly, 260-271.

Belman, D., Drago, R., \& Wooden, M. (1992). Workgroups, efficiency wages and work effort. Journal of Post Keynesian Economics, 14(4), 497-521.

Brewer, N. (1995). The Effects of Monitoring Individual and Group Performance on the Distribution of Effort Across Tasks1. Journal of Applied Social Psychology, 25(9), 760-777.

Brooks, C. M., \& Ammons, J. L. (2003). Free riding in group projects and the effects of timing, frequency, and specificity of criteria in peer assessments. The Journal of Education for Business, 78(5), 268-272.

Brownell, P. (1995). Research methods in management accounting: Coopers and Lybrand and Accounting Association of Australia and New Zealand. 
Chidambaram, L., \& Tung, L. L. (2005). Is out of sight, out of mind? An empirical study of social loafing in technology-supported groups. Information Systems Research, 16(2), 149168.

Comer, D. R. (1995). A model of social loafing in real work groups. Human Relations, 48(6), 647-667.

Cooper, D. R., \& Schindler, P. S. (2003). Business research methods.

Davies, W. M. (2009). Groupwork as a form of assessment: common problems and recommended solutions. Higher Education, 58(4), 563-584.

DeNisi, A. S., Randolph, W. A., \& Blencoe, A. G. (1983). Potential problems with peer ratings. Academy of Management Journal, 26(3), 457-464.

Edmondson, A. (1999). Psychological safety and learning behavior in work teams. Administrative Science Quarterly, 44(2), 350-383.

Falchikov, N., \& Goldfinch, J. (2000). Student peer assessment in higher education: A metaanalysis comparing peer and teacher marks. Review of educational research, 70(3), 287-322.

George, J. M. (1992). Extrinsic and intrinsic origins of perceived social loafing in organizations. Academy of Management Journal, 35(1), 191-202.

Gerhart, B., \& Rynes, S. (2003). Compensation: Theory, evidence, and strategic implications: SAGE Publications, Incorporated.

Gladstein, D. L. (1984). Groups in context: A model of task group effectiveness. Administrative Science Quarterly, 499-517.

Glance, N. S., \& Huberman, B. A. (1994). The dynamics of social dilemmas. Scientific American, 270(3), 76-81.

Goethals, G. R., \& Darley, J. M. (1987). Social comparison theory: Self-evaluation and group life Theories of group behavior (pp. 21-47): Springer.

Goodman, R. (1997). The Strengths and Difficulties Questionnaire: a research note. Journal of child psychology and psychiatry, 38(5), 581-586.

Griffith, T. L., Fichman, M., \& Moreland, R. L. (1989). Social loafing and social facilitation: An empirical test of the cognitive-motivational model of performance. Basic and applied social psychology, 10(3), 253-271.

Hardy, C. J., \& Crace, R. K. (1991). The effects of task structure and teammate competence on social loafing. Journal of Sport \& Exercise Psychology.

Harkins, S. G., \& Jackson, J. M. (1985). The role of evaluation in eliminating social loafing. Personality and Social Psychology Bulletin, 11(4), 457-465.

Harkins, S. G., \& Szymanski, K. (1989). Social loafing and group evaluation. Journal of Personality and Social Psychology, 56(6), 934.

Hoon, H., \& Tan, T. M. L. (2008). Organizational citizenship behavior and social loafing: The role of personality, motives, and contextual factors. The Journal of psychology, 142(1), 89-108.

Jackson, J. M., \& Harkins, S. G. (1985). Equity in effort: An explanation of the social loafing effect. Journal of Personality and Social Psychology, 49(5), 1199. 
Karau, S. J., \& Williams, K. D. (1993). Social loafing: A meta-analytic review and theoretical integration. Journal of Personality and Social Psychology, 65(4), 681.

Kidwell, R. E., \& Bennett, N. (1993). Employee propensity to withhold effort: A conceptual model to intersect three avenues of research. Academy of Management Review, 18(3), 429456.

Kiesler, S. B. (1978). Interpersonal processes in groups and organizations: AHM Publishing Corporation.

Klehe, U. C., \& Anderson, N. (2007). The moderating influence of personality and culture on social loafing in typical versus maximum performance situations. International Journal of Selection and Assessment, 15(2), 250-262.

Kravitz, D. A., \& Martin, B. (1986). Ringelmann rediscovered: The original article.

Kremer, J., \& McGuinness, C. (1998). Cutting the cord: Student-led discussion groups in higher education. Education+ Training, 40(2), 44-49.

Latane, B., Williams, K., \& Harkins, S. (1979). Many hands make light the work: The causes and consequences of social loafing. Key Readings in Social Psychology, 1, 297.

Lawler, E. E. (2000). Rewarding excellence (Vol. 13): Jossey-Bass San Francisco.

Liden, R. C., Wayne, S. J., Jaworski, R. A., \& Bennett, N. (2004). Social loafing: A field investigation. Journal of Management, 30(2), 285-304.

Lipsey, M. W., Freeman, H., \& Rossi, P. (2004). Evaluation: a systematic approach. Thousand Oaks, CA, Sage.

Loch, C. H., Huberman, B. A., \& Stout, S. (2000). Status competition and performance in work groups. Journal of Economic Behavior \& Organization, 43(1), 35-55.

Locke, E. A., Cartledge, N., \& Koeppel, J. (1968). Motivational effects of knowledge of results: A goal-setting phenomenon? Psychological bulletin, 70(6p1), 474.

Locke, E. A., Feren, D. B., McCaleb, V. M., Shaw, K. N., \& Denny, A. T. (1980). The relative effectiveness of four methods of motivating employee performance. Changes in working life, 363, 388.

Locke, E. A., \& Latham, G. P. (1990). A theory of goal setting \& task performance: PrenticeHall, Inc.

Locke, E. A., Shaw, K. N., Saari, L. M., \& Latham, G. P. (1981). Goal setting and task performance: 1969-1980. Psychological bulletin, 90(1), 125.

Marks, M. A., Sabella, M. J., Burke, C. S., \& Zaccaro, S. J. (2002). The impact of crosstraining on team effectiveness. Journal of Applied Psychology, 87(1), 3.

Ness, R. G., \& Patton, R. W. (1979). The effect of beliefs on maximum weight-lifting performance. Cognitive Therapy and Research, 3(2), 205-211.

Pallant, J. (2010). SPSS survival manual: A step by step guide to data analysis using SPSS: McGraw-Hill International.

Payne, R., \& Pugh, D. S. (1976). Organizational structure and climate. Handbook of industrial and organizational psychology, 1125, 1173.

Pfeffer, J. (1995). Competitive advantage through people: Unleashing the power of the work force: Harvard Business Press. 
Price, K. H. (1987). Decision responsibility, task responsibility, identifiability, and social loafing. Organizational behavior and human decision processes, 40(3), 330-345.

Pugh, D. S., Hickson, D. J., Hinings, C. R., \& Turner, C. (1968). Dimensions of organization structure. Administrative Science Quarterly, 65-105.

Rand, A. (1990). Introduction to Objectivist Epistemology: Expanded Second Edition: Penguin. com.

Rees, D. I., Zax, J. S., \& Herries, J. (2003). Interdependence in worker productivity. Journal of Applied Econometrics, 18(5), 585-604.

Rubin, A., \& Babbie, E. (2013). Brooks/Cole Empowerment Series: Research Methods for Social Work: Cengage Learning.

Russ-Eft, D. F. (2009). Evaluation in organizations: A systematic approach to enhancing learning, performance, and change: Basic Books.

Shea, G. P., \& Guzzo, R. A. (1987). Group effectiveness: What really matters. Sloan Management Review, 28(3), 25-31.

Steiner, L. (2007). Group Process and Productivity (Social Psychological Monograph).

Strong, J. T., \& Anderson, R. E. (1990). Free-riding in group projects: Control mechanisms and preliminary data. Journal of Marketing Education, 12(2), 61-67.

Suleiman, J., \& Watson, R. T. (2008). Social loafing in technology-supported teams. Computer Supported Cooperative Work (CSCW), 17(4), 291-309.

Szymanski, K., \& Harkins, S. G. (1987). Social loafing and self-evaluation with a social standard. Journal of Personality and Social Psychology, 53(5), 891.

Tabachnick, B. G., \& Fidell, L. S. (2001). Using multivariate statistics.

Thompson, L. L. (2004). Making the team: A guide for managers: Pearson Education India.

Veigal, J. F. (1991). The frequency of self-limiting behavior in groups: A measure and an explanation. Human Relations, 44(8), 877-895.

Wageman, R. (1995). Interdependence and group effectiveness. Administrative Science Quarterly, 145-180.

Wageman, R., \& Baker, G. (1997). Incentives and cooperation: The joint effects of task and reward interdependence on group performance. Journal of organizational behavior, 18(2), 139-158.

Watson, W. E., Kumar, K., \& Michaelsen, L. K. (1993). Cultural diversity's impact on interaction process and performance: Comparing homogeneous and diverse task groups. Academy of Management Journal, 36(3), 590-602.

Williams, K. D., Nida, S. A., Baca, L. D., \& Latané, B. (1989). Social loafing and swimming: Effects of identifiability on individual and relay performance of intercollegiate swimmers. Basic and applied social psychology, 10(1), 73-81.

Worchel, S., Rothgerber, H., Day, E. A., Hart, D., \& Butemeyer, J. (1998). Social identity and individual productivity within groups. British Journal of Social Psychology, 37(4), 389-413.

Wright, K. B. (2005). Researching Internet-based populations: Advantages and disadvantages of online survey research, online questionnaire authoring software packages, and web survey services. Journal of Computer-Mediated Communication, 10(3), 00-00. 